\title{
STRATEGI PUSKESMAS KUTA II DALAM MEMPERTAHANKAN DAN MENINGKATKAN MUTU PELAYANAN KESEHATAN PADA MASA PANDEMI COVID-19
}

\author{
Ni Komang Yudi Sri Astari, Pande Putu Januraga* \\ Program Studi Sarjana Kesehatan Masyarakat Fakultas Kedokteran Universitas Udayana \\ Jalan P.B. Sudirman, Kec. Denpasar Barat, Kota Denpasar, Bali 80234
}

\begin{abstract}
ABSTRAK
Puskesmas sebagai salah satu penyedia layanan kesehatan bagi masyarakat perlu memiliki mutu pelayanan yang berkualitas sesuai dengan harapan masyarakat untuk dapat menjaga kepuasan serta kepercayaan pasien khususnya di masa pandemi COVID-19 seperti saat ini. Tujuan penelitian ini untuk mengetahui strategi dalam mempertahankan dan meningkatkan mutu pelayanan kesehatan pada masa pandemi COVID-19 di Puskesmas Kuta II Kabupaten Badung. Penelitian ini menggunakan metode kualitatif. Informan dari penelitian ini merupakan petugas dari Puskesmas Kuta II sejumlah 17 orang yang dipilih melalui teknik purposive sampling. Instrumen pengumpulan data menggunakan pedoman wawancara mendalam dan lembar observasi. Analisis data dilakukan dengan reduksi data, penyajian data, serta penarikan kesimpulan atau verifikasi. Hasil penelitian menunjukkan bahwa strategi yang ditetapkan oleh Puskesmas Kuta II dalam mempertahankan dan meningkatkan mutu pelayanan kesehatan pada masa pandemi COVID-19 telah mencakup seluruh aspek yang terdapat pada 4 prinsip penjaminan mutu dan 5 dimensi mutu dengan lebih menekankan pada selalu memenuhi kebutuhan atau harapan pelanggan dengan berusaha memberikan fasilitas yang baik serta memberikan pelayanan yang cepat, tepat, dan aman. Namun, dalam pelaksanaan strategi tersebut terdapat beberapa kendala seperti terbatasnya tempat yang ada dan SDM yang belum memadai. Oleh sebab itu, diperlukan adanya peningkatan manajemen SDM dan peningkatan penataan ruangan di puskesmas.
\end{abstract}

Kata Kunci: Strategi, Mutu Pelayanan Kesehatan, Puskesmas

\begin{abstract}
Public health center as one of the providers of health services for the community needs to have quality services according to community expectations to maintain patient satisfaction and trust, especially during the COVID-19 pandemic. The study aims to find out the strategies for maintaining and improving the quality of health services during the COVID-19 pandemic at Kuta II Public Health Center, Badung Regency. This study was designed by qualitative methods. The informants of this study were officers from the Kuta II Public Health Center which were a total of 17 people selected through purposive sampling technique.The instrument for data collection was in-depth interview guidelines and observation sheets. Data analysis was carried out by data reduction, data presentation, and drawing conclusions or verification. The results of this study indicate that the defined strategy by Kuta II Public Health Center in maintaining and improving the quality of health services during the COVID-19 pandemic has covered all aspects of the 4 principles of quality assurance and 5 dimensions of quality. The implemented strategy has always emphasizes to fulfill customer needs or expectations by trying to provide good facilities and provide fast, precise, and safe service, especially during the COVID-19 pandemic. However, in the implementation of this strategy there are several obstacles such as the limited space and inadequate human resources. Therefore, it is necessary to improve the human resources management and improve the arrangement of the public health center.
\end{abstract} Keyword: Strategy, Quality Of Health, Public Health Center

\section{PENDAHULUAN}

Menurut Peraturan Menteri

Kesehatan Republik Indonesia Nomor 75

Tahun 2014 Tentang Pusat Kesehatan Masyarakat, puskesmas merupakan FKTP yang menyelenggarakan UKM dan UKP dengan lebih mengutamakan upaya promotif dan preventif guna mencapai derajat kesehatan masyarakat yang optimal di wilayah kerjanya. Sebagai salah satu penyedia layanan kesehatan bagi masyarakat, puskesmas perlu memiliki mutu pelayanan yang berkualitas sesuai dengan harapan masyarakat untuk dapat menjaga kepuasan serta kepercayaan pasien. Mutu pelayanan kesehatan adalah 
pelayanan kesehatan yang dapat memberikan kepuasan kepada setiap pasien atau pengguna jasa pelayanan kesehatan yang sesuai dengan tingkat kepuasan rata - rata dan juga penyelenggaraannya yang sesuai dengan kode etik profesi (Azrul, 2010). Dalam suatu institusi kesehatan, mutu pelayanan merupakan hal yang sangat penting karena dapat mempengaruhi kepuasan pasien. Mutu pelayanan kesehatan yang baik akan memberikan kepuasan kepada pasien. Jika kepuasan pasien tidak terpenuhi maka akan berdampak terhadap menurunnya jumlah kunjungan pasien yang kemudian dapat mempengaruhi profitabililas dari suatu institusi kesehatan (Azwar, 1994).

Saat ini, pandemi COVID-19 merupakan suatu permasalahan yang sedang dihadapi oleh seluruh dunia, termasuk Indonesia. COVID-19 merupakan virus yang menyebabkan penyakit infeksi saluran pernapasan pada manusia mulai dari flu biasa hingga penyakit serius seperti MERS dan SARS (Kemenkes RI, 2020a). Di masa pandemi seperti ini menjadi tantangan terbesar yang harus dihadapi oleh institusi kesehatan dalam memberikan pelayanan kesehatan yang optimal kepada masyarakatnya dan juga harus menjaga mutu pelayanan kesehatan agar pasien tetap merasa puas dengan pelayanan kesehatan yang diberikan. Untuk tetap menjaga mutu pelayanan tersebut, institusi kesehatan memerlukan adanya suatu strategi. Strategi merupakan seperangkat aktivitas yang dilakukan oleh suatu perusahaan, organisasi, ataupun seseorang untuk dapat mencapai tujuan dan sasaran yang diinginkan sehingga dapat memperoleh keunggulan selama berkompetisi agar dapat lebih baik dari pesaingnya (Aminingrum and Niswah, 2013).

Puskesmas Kuta II merupakan unit kerja yang berada di bawah Dinas Kesehatan Kabupaten Badung dan bertanggung jawab atas terlaksananya program kesehatan di dua wilayah binaan yaitu Kelurahan Legian dan Kelurahan Seminyak. Puskesmas Kuta II adalah puskesmas Non Rawat Inap dengan pelayanan UGD 24 Jam dan dengan status akreditasi madya. Berdasarkan hasil data tiga tahun terakhir pada Puskesmas Kuta II, terjadi peningkatan jumlah kunjungan setiap tahunnya. Pada kunjungan rawat jalan tahun 2017 terdapat kunjungan sebanyak 7.224 pasien, tahun 2018 sebanyak 9.926 pasien, dan tahun 2019 sebanyak 15.751 pasien. Namun, pada tahun 2020 jumlah kunjungan mengalami penurunan menjadi 11.646 pasien (Dinas Kesehatan Kabupaten Badung, 2020).

Berdasarkan hasil wawancara dengan salah satu dokter yang bertugas di Puskesmas Kuta II, dimasa pandemi COVID-19 layanan kesehatan tetap berjalan sebagaimana mestinya. Namun, terdapat beberapa perbedaan dengan layanan kesehatan yang diberikan antara sebelum dan sesudah adanya pandemi COVID-19 yakni adanya pembatasan jam pelayanan dimana awalnya pelayanan diberikan mulai pukul 08.00 sampai 13.00 tetapi saat ini berubah menjadi pukul 08.00 sampai 12.00. Jika setelah pukul 12.00 terdapat pasien yang ingin berobat dan keluhan pasien termasuk dalam kategori emergency maka pasien akan diberikan layanan kesehatan di UGD tetapi jika tidak emergency maka pasien akan diberikan KIE 
dan dihimbau untuk datang kembali ke puskesmas keesokan harinya. Kemudian, terdapat perubahan alur pelayanan pada UKP yaitu di bagian depan terdapat skrining yang melakukan pemilahan pasien dimana jika terdapat pasien yang memiliki gejala seperti batuk, pilek, panas, maupun gejala lainnya yang merujuk pada gejala COVID-19 maka pasien tersebut akan diarahkan ke poli infeksius untuk mendapatkan pelayanan di poli infeksius. Sedangkan, jika tidak terdapat gejala yang merujuk pada COVID-19 maka akan diarahkan ke poli yang dibutuhkan.

Terdapatnya perubahan dalam pemberian pelayanan kesehatan pada masa pandemi COVID-19 di puskesmas akan berpengaruh terhadap mutu pelayanan kesehatan. Pentingnya mutu pelayanan kesehatan pada institusi kesehatan khususnya di puskesmas pada masa pandemi COVID-19 maka penulis tertarik untuk melakukan penelitian mengenai "Strategi Puskesmas Kuta II dalam Mempertahankan dan Meningkatkan Mutu Pelayanan Kesehatan pada Masa Pandemi COVID-19"

\section{METODE PENELITIAN}

Penelitian ini adalah penelitian kualitatif. Penelitian ini menggali secara rinci mengenai strategi Puskesmas Kuta II dalam mempertahankan dan meningkatkan mutu pelayanan kesehatan pada masa pandemi COVID-19 berdasarkan 4 prinsip penjaminan mutu dan 5 dimensi mutu. Penelitian ini dilaksanakan pada bulan Mei-Juni 2021. Teknik pengumpulan data yang digunakan adalah wawancara mendalam dan observasi. Subyek penelitian dipilih berdasarkan teknik purposive sampling. Jumlah informan sebanyak 17 orang dari Puskesmas Kuta II yang terdiri dari kepala puskesmas, kepala sub bagian tata usaha, penanggungjawab mutu pelayanan kesehatan, petugas kesehatan dan petugas loket. Pada penelitian ini, teknik analisis data yang digunakan yaitu reduksi data, penyajian data, dan penarikan kesimpulan. Validitas data dalam penelitian ini dilakukan dengan triangulasi sumber dan triangulasi metode. Penelitian ini telah dinyatakan laik etik berdasarkan Keterangan Kelaikan Etik Nomor: 107/UN14.2.2.VII.14/LT/2021.

\section{HASIL}

Strategi Berdasarkan $4 \quad$ Prinsip Penjaminan Mutu

\section{a. Fokus Terhadap Pelanggan}

Ditinjau dari fokus terhadap pelanggan, cara yang dilakukan puskesmas dalam mengumpulkan informasi mengenai kebutuhan/harapan pelanggan yaitu melalui kotak saran, sosial media seperti facebook, instagram, email, whatsapp serta menggunakan kuesioner kepuasan pelanggan untuk melihat kritik, saran, serta kepuasan dari pelanggan.

"Kita ada kotak saran, kuesioner, dan ada juga melalui sosial media, kayak instagram, facebook, whatsapp, dan email." (drg_06)

Selain itu, puskesmas juga melaksanakan rapat lintas sektor dengan tokoh masyarakat, musrenbang, serta rapat dengan kader posyandu untuk menyamakan misi tokoh masyarakat, kader posyandu untuk meningkatkan derajat kesehatan masyarakat di wilayah kerja Puskesmas Kuta II. 
“.. selain itu, nanti ada rapat - rapat lintas sektor, musrenbang, ada juga rapat dengan kader - kader posyandu." (drg_07)

Dalam hal ini, petugas yang berperan dalam mengumpulkan informasi tersebut yaitu tim kepuasan pasien, tim keluhan pelanggan serta tim informasi.

"Untuk kotak saran, kritik dan saran itu kita ada namanya tim keluhan pelanggan sama tim kepuasan pelanggan. Kalo untuk sosial medianya itu tim informasi." (dr_05)

Sebagai upaya tindaklanjut terkait kebutuhan/harapan pelanggan, petugas Puskemas Kuta II akan melakukan pengecekan kotak saran yang dilaksanakan setiap hari selesai pelayanan sehingga dapat dikoordinasikan oleh tim keluhan pelanggan dan dapat memberikan umpan balik kepada pelanggan.

"Siangnya setelah selesai layanan kita buka kotak sarannya. Nanti tim keluhan pelanggan akan koordinasi tentang masukan - masukan itu jadi kita bisa memberikan umpan balik ke pelanggan." (PJMutu_03)

Kemudian, untuk informasi yang diperoleh melalui sosial media akan direspon saat itu juga. Jika diperlukan koordinasi dengan pimpinan maka akan dilakukan koordinasi. Apabila sudah mendapatkan keputusan final maka akan diinformasikan kembali kepada pelanggan tersebut.

"Untuk sosial media itu kita punya tim informasi sendiri, kalo ada kritik atau saran langsung jawab hari itu juga. Kalo perlu untuk mengkoordinasikan dengan pimpinan itu biasanya akan ditampung dulu masukan. Setelah mendapat jawaban dari pimpinan baru kita konfirmasi kembali." (dr_05)

Kemudian, untuk informasi yang diperoleh melalui rapat lintas sektor juga akan ditampung dan dipilah antara yang sekiranya dapat dilakukan dan tidak dapat dilakukan berdasarkan atas persetujuan kepala puksesmas melalui arahan dinas kesehatan sehingga nantinya hal tersebut akan dituangkan dalam RUK puskesmas. "Jadi masukan - masukan itu akan kita tampung dan kita pilih mana akan bisa kita lakukan dan yang tidak bisa kita lakukan yang tentunya itu berdasarkan persetujuan dari kepala puskesmas melalui arahan dinas. Nanti kalo memang kegiatannya sudah disetujui, kita akan tuangkan dalam rencana kinerja kita berupa RUK disana usulan rencana masing masing program." (drg_07)

\section{b. Fokus pada Sistem dan Proses}

Ditinjau dari jumlah sumber daya manusia, saat ini sumber daya manusia di Puskesmas Kuta II belum memadai, khususnya saat ini yang sedang digencarkan kegiatan vaksinasi sehingga menyebabkan tenaga di puskesmas berkurang.

"Kalo secara keseluruhan, apalagi karna banyak kegiatan seperti saat ini ada kegiatan vaksinasi itu kurang ya." (Bidan_13)

Selain karena tugas keluar, puskesmas juga kekurangan beberapa tenaga seperti sopir, admin, ahli gizi, dan rekam medis sehingga terdapat beberapa petugas yang menjalankan pekerjaannya tidak sesuai dengan kompetensi yang dimiliki.

"Saat ini belum memadai. Jadi beberapa tenaga yang dibutuhkan itu tidak sesuai dengan kompetensinya. Saat ini puskesmas masih kurang tenaga sopir, admin, ahli gizi, dan rekam medis kita belum punya." (KaPus_01)

Oleh sebab itu, puskesmas berusaha memaksimalkan SDM yang ada dalam 
bekerja dan mengajukan permohonan untuk penambahan SDM ke dinas kesehatan sehingga diharapkan SDM yang kurang tersebut dapat terpenuhi.

"Kita memanfaatkan pegawai yang ada di puskesmas walaupun kerjaannya jadi merangkap tapi kita selalu usahakan untuk memberikan pelayanan yang baik Kita sudah ajukan ke kabupaten terkait hal ini dan iya masih di proses karena untuk perekrutan itu melihat juga juknis dari kabupaten." (KaPus_01)

Ditinjau dari dana, saat ini di masa pandemi COVID-19 pendapatan puskesmas mengalami penurunan karena sebagian besar masyarakat masih takut datang ke puskesmas untuk mendapatkan pelayanan kesehatan. Agar semua keperluan dapat terpenuhi maka puskesmas melakukan penyusunan RKA dengan menggunakan skala prioritas.

"Pendapatan puskesmas selama pandemi itu menurun soalnya masyarakat juga masih takut ke puskesmas. Biar semua dana mencukupi kita mengatur semua rencana kegiatan anggaran kita dengan skala prioritas." (KaPus_01)

Dana yang digunakan untuk menunjang segala kebutuhan dan kegiatan di puskesmas berasal dari pendapatan BLUD (JKN dan retribusi), DAK non fisik, serta dana yang bersumber dari APBD.

“Untuk dana yang kita gunakan di puskesmas itu ada dari pendapatan BLUD yang terdiri dari JKN dan retribusi, ada DAK non fisik, sama ada dari APBD" (PJMutu_03)

Dana yang dikelola oleh puskesmas adalah pendapatan BLUD (JKN dan retribusi) dengan proporsi alokasi dana sebesar $60 \%$ untuk jasa pelayanan serta $40 \%$ untuk operasional di puskesmas. Kemudian, untuk DAK non fisik saat ini digunakan untuk kegiatan UKM sebesar $60 \%$ sedangkan $40 \%$ dari dana tersebut digunakan untuk penanganan COVID-19. Selain itu, penanganan COVID-19 juga menggunakan dana yang berasal dari APBD yang dikelola oleh dinas kesehatan. "Dana yang kita kelola itu dari pendapatan BLUD yang terdiri dari JKN dan retribusi. JKN ini untuk operasional $40 \%$ dan jasa pelayanan $60 \%$, begitu juga dari sumber retribusi yang sesuai tarif yang tercantum dalam perda retribusi. Kalo untuk DAK non fisik itu untuk kegiatan UKM tapi karna pandemi jadi ada perubahan, perubahannya itu dari DAK non fisik maksimal 40\% kita gunakan untuk penanganan COVID-19. Selain itu, untuk penanganan COVID-19 ada juga didanai dari APBD yang dikelola dinas kesehatan." (KaPus_01)

Ditinjau dari ketersediaan sarana dan prasarana dapat dikatakan cukup memadai. Di masa pandemi COVID-19 terdapat penambahan sarana dan prasarana yaitu tempat cuci tangan yang diletakkan di depan gedung, terdapatnya poli infeksius bagi pasien yang memiliki gejala yang merujuk pada COVID-19, terdapatnya pelayanan swab antigen dan swab PCR, serta penambahan sekat pembatas transparan di bagian loket pendaftaran guna meminimalisir terjadinya penularan COVID-19 antara pasien dengan petugas.

"Kalo sarana sih sebenarnya sudah cukup. Nah di masa pandemi ini kita ada penambahan sarana dan prasarana kayak tempat cuci tangan, poli infeksius untuk pasien yang punya keluhan panas, batuk, dan pilek, di loket pendaftaran ada sekat transparannya sama kita sekarang ada pelayanan swab antigen dan PCR setiap hari senin dan jumat." (Lab_14) 
Puskesmas juga memiliki rencana untuk menambah sarana dan prasarana kembali agar dapat memberikan pelayanan yang lebih baik lagi seperti melakukan perbaikan gedung, penambahan incenerator, printer, komputer, dan mobil puskesmas.

“.masih ada yang kurang - kurang kayak gedung kita saat ini kurang memadai karena tempat yang bisa dibilang kecil juga, incenerator, komputer, printer, dan mobil puskesmas itu masih kurang. Iya kita rencana untuk menambah sarana prasarana yang kurang itu." (KaPus_01)

Dalam penyelenggaraan pelayanan kesehatan, Puskesmas Kuta II selalu mengikuti SOP agar dapat memberikan pelayanan yang tepat kepada pengunjung. "Iya, kita disini selalu mengikuti SOP yang berlaku." (Bidan_12)

Namun dalam situasi pandemi COVID-19 seperti saat ini, informan menyatakan bahwa terdapat kendala dalam penyelenggaraannya seperti harus menjaga jarak, pelayanan di poli gigi yang memiliki risiko tinggi terhadap penularan COVID-19, serta terbatasnya kegiatan on call pasien.

"Ada, kita harus jaga jarak, untuk kegiatan on call pasien pun kita terbatas sekarang karena keadaan seperti ini jadi harus hati - hati juga kan dari kita sendiri, kita menolong pasien juga." (dr_05)

"Semenjak pandemi, pelayanan poli gigi itu berisiko banget karna kita ada open mouth nya kan jadi itu sih kendalanya." (drg_06)

Untuk mengatasi kendala tersebut, maka dilakukan kegiatan mitigasi untuk memisahkan pasien infeksius dan non infeksius, terdapatnya identifikasi risiko, adanya pembatasan pemberian pelayanan tindakan di poli gigi yaitu hanya setiap hari senin dan kamis, serta menggunakan APD saat kegiatan on call pasien.

"On call itu kita tetep jalan, kalo sekiranya tidak terkonfirmasi positif ya kita menggunakan APD level 2. Kalo misalkan pasien terkonfirmasi positif kita menggunakan APD level 3." (dr_05)

"Kita lakukan kegiatan mitigasi dan identifikasi risiko. Untuk di poli gigi juga kita ngambil tindakannya terbatas, sekarang cuma 2 kali seminggu di hari senin sama kamis dan kita pakai jas hasmat. Jadi selain itu, kita cuma melayani untuk konsultasi dan pemberian obat." (drg_06)

\section{c. Fokus Terhadap Data Untuk Mengambil Keputusan}

Dalam mengambil keputusan, data yang digunakan puskesmas yaitu capaian program dan capaian kinerja puskesmas sehingga dapat dibandingkan antara yang telah direncanakan dengan yang tercapai di lapangan.

"Kita menggunakan hasil capaian program dan capaian kinerja puskesmas nya. Kita lihat dari capaian kinerja setiap bulan, kalo tidak jalan apa yang harus kita lakukan." (KaTU_02)

Puskesmas juga menggunakan indeks kepuasan masyarakat untuk melihat tingkat kepuasan pelanggan agar dapat meningkatkan kinerja dalam memberikan pelayanan kesehatan.

“..IKM kita juga pakai, jadi kita tau apakah pelanggan puas atau tidak dengan pelayanan yang kita berikan. Kalo misalkan ada yang tidak puas ya kita akan tingkatkan lagi biar pasien merasa puas." (KaPus_01)

Kemudian, puskesmas juga melihat dari ketersediaan sarana dan prasarana sehingga dapat direncanakan dan 
dilakukan pengadaan terhadap sarana dan prasarana yang kurang tersebut.

“.. kita juga melihat ketersediaan sarana prasarana, jadi kita tau apa yang harus kita tambah untuk menunjang segala kegiatan pelayanan kesehatan." (KaPus_01)

Disisi lain, puskemas juga melihat dari hasil audit internal dan audit klinis untuk melihat apakah pelayanan yang diberikan sudah sesuai dengan SOP yang telah ditetapkan. Sehingga nantinya dapat ditindaklanjuti apabila pelayanan yang diberikan tidak sesuai dengan SOP.

"..kemudian ada hasil audit internal dan audit klinis. Jadi nanti kita lihat petugas itu udah sesuai atau belum sama SOP yang telah ditetapkan. Kalo belum ya akan ditindaklanjuti, jadi kasi tau lagi biar sesuai sama SOP yang ada." (KaPus_01)

Puskesmas juga mengambil keputusan melihat dari hasil SMD/MMD untuk mengetahui masalah kesehatan yang dialami oleh masyarakat sehingga dapat dilakukan tindaklanjut untuk mengatasi masalah tersebut.

“..jadi masukan dari masyarakat itu saat kita melakukan SMD dan MMD itu dari sana juga datanya kita ambil. Nah kemudian data - data ini di proses untuk dapat mengambil keputusan apa yang harus kita lakukan nantinya." (PJMutu_03)

\section{d. Fokus Pada Kerja Tim}

Ditinjau dari kerja tim, kerjasama tim di puskesmas dalam memandang suatu permasalahan dan mengambil keputusan yaitu dengan melaksanakan rapat mutu UKM, UKP, dan admen setiap minggu yang membahas masing - masing program kerja yang dimiliki, rapat tinjauan manajemen setiap tiga bulan yang membahas terkait kepuasan pelanggan, keluhan pelanggan, laporan audit internal dan audit klinis, serta rapat rutin setiap bulan untuk membahas kinerja atau kegiatan yang dilaksanakan di bulan lalu sehingga dapat dilakukan peningkatan kinerja di bulan berikutnya.

"Jadi ada beberapa rapat yang dilaksanakan. rapat mutu UKM, UKP, dan admen setiap minggu, ada RTM setiap 3 bulan dan rapat rutin yang kita laksanakan setiap bulan." (KaPus_01)

Selain itu dalam membangun kerja tim yang baik, Puskesmas Kuta II juga rutin melaksanakan apel setiap hari di pagi hari yang di pimpin oleh kepala puskesmas guna dapat menjalin komunikasi yang baik antar petugas, membangun semangat kerja, serta membina kekompakan atau kerjasama antar petugas. Namun, apel ini tidak dilaksanakan lagi karena pandemi COVID-19 sehingga kepala puskesmas hanya rutin memberikan informasi melalui whatsapp grup dan diharapkan antar petugas tetap bekerjasama dengan baik di masa pandemi COVID-19.

"Sebelum pandemi kita rutin melakukan briefing kepada pegawai. Briefing ini kita lakukan setiap hari saat apel pagi, jadi kita harapkan dengan briefing itu bisa menjalin komunikasi yang baik antar petugas, membangun semangat kerja, sama kita bisa membina kekompakan atau kerjasama antar petugas. Tapi karena pandemi, kita hanya lakukan lewat WA grup dengan memberikan informasi - informasi itu." (KaPus_01)

Dalam kerja tim ini tidak menutup kemungkinan terjadinya perbedaan pendapat antara setiap anggota. Oleh sebab itu, Puskesmas Kuta II mengatasinya 
dengan cara musyawarah mufakat sesuai aturan dan acuan serta menggunakan voting dengan tetap memperhatikan situasi dan kondisi di lapangan.

"Kita memutuskan sesuatu itu tetep berdasarkan atas aturan dan acuan yang mana kita bisa terapkan dan kita lihat juga situasi di lapangan dengan musyawarah mufakat atau voting. Nanti akan kita satukan menjadi satu keputusan secara bersama - sama yang bisa kita laksanakan secara bersama - sama." (drg_07)

\section{Strategi Berdasarkan 5 Dimensi Mutu}

\section{a. Dimensi Bukti Fisik (tangibles)}

Ditinjau berdasarkan penataan ruangan, beberapa informan menyatakan bahwa penataan ruangan di Puskesmas Kuta II dapat dikatakan cukup.

"Penataan ruangan sementara sih sudah cukup baik untuk kelas puskesmas."(Lab_15)

Namun, terdapat beberapa informan yang menyatakan bahwa penataan ruangan masih kurang. Hal ini disebabkan karena tempat puskesmas yang kecil sehingga beberapa ruangan seperti UGD dan poli umum masih menjadi satu dan hanya dipisah dengan sekat, belum tersedianya ruangan konseling remaja dan lansia, ruang rekam medis yang kecil, serta poli infeksius yang berada diluar gedung.

"Kalo untuk penataan ruangan memang kurang seperti ruangan poli umum dan UGD masih jadi satu dan hanya dibatasi dengan sekat, belum ada ruangan untuk konseling remaja dan lansia. Untuk ruangan infeksius pun sekarang kita pakai yang diluar ruangan, untuk ruang RM juga sempit. Jadi memang masih terbatas sekali karna memang tempatnya yang kecil." (dr_05)

Kemudian, puskesmas juga selalu menjaga kebersihan dengan rutin melakukan sterilisasi ruangan setiap selesai pelayanan dan sterilisasi seluruh puskesmas setiap hari sabtu.

"Sterilisasi sering, sering dilakukan penyemprotan disinfektan sama CS-nya. Jadi selesai pelayanan itu disemprot, trus ada nanti kegiatan penyemprotan besar diseluruh puskesmas dihari sabtu." (Prwt_11)

Hal ini didukung dari hasil pengamatan peneliti yaitu sebelum dan sesudah pelayanan terdapat petugas yang menyapu ruangan serta melakukan sterilisasi dengan menyemrotkan alkohol kemudian dilap disetiap permukaan yang sering disentuh. Selain itu, untuk ruang tunggu bagi pasien juga sudah ditata dengan baik yaitu menjaga jarak sesuai dengan menerapkan protokol kesehatan yakni memberikan tanda $X$ pada kursi tersebut.

"Seperti yang dilihat disana sudah berisi tanda $x$, jelas sudah pasti menjaga jarak, prokes tetap kita lakukan." (drg_07)

Kemudian, ditinjau dari peralatan kesehatan yang digunakan dalam pemberian pelayanan kesehatan saat ini sudah lengkap dalam standar puskesmas dan bersih karena dilakukan sterilisasi setiap selesai pelayanan.

"Kalo untuk alat kesehatan itu sudah lengkap dan setelah memberikan tindakan biasa kita rendem, cuci, kita strerilisasi saat sudah tutup poli." (Prwt_10)

Pernyataan informan sesuai dengan hasil pengamatan peneliti yakni setiap petugas selesai memberikan pelayanan kepada pasien, alat kesehatan yang digunakan akan langsung dibersihkan dan dilakukan sterilisasi.

Selain itu, jika ditinjau dari persediaan obat dalam pemberian 
pelayanan kesehatan di puskesmas dapat dikatakan lengkap karena puskesmas cenderung menggunakan obat generik.

“Lumayan lengkap karna kan puskesmas cuma pakai obat dasar aja, kita udah ada selain obat dasar dan udah ada apoteker juga." (dr_04)

Namun, dalam persediaan obat ini tidak menutup kemungkinan terjadinya kekosongan ataupun kekurangan karena pengadaan obat bersumber dari dinas kesehatan.

"Kalo obat itu kadang kita pernah kosong. Nah, kalo obat di puskesmas itu kita ada yang sumbernya dari dinas jadi kita dapet drop dari dinas sesuai perencanaan kita setiap tahun. Jadi obat yang dari dinas dikumpulkan di IFK nanti dikirimkan kesini. Kadang disitu dah jeda nya itu pasti ada kurang lebih kosong seminggu dua minggu jadinya harus nunggu obat datang." (apt_08)

Untuk mengatasi kekosongan obat tersebut, puskesmas mengatasinya dengan cara melakukan peminjaman obat ke puskesmas terdekat ataupun mengadakan obat sendiri dengan menggunakan pendapatan BLUD.

"Kalo misalnya obat kosong dan mungkin di IFK sudah datang, kita ada puskesmas terdekat disini jadi pinjem dulu nanti kembalikan dengan stok di IFK." (apt_08)

"Jadi ada namanya pendapatan BLUD, kalo kita memang punya dana itu kita masih bisa beli obat sendiri." (TTK_09)

Dalam pemeliharaan sarana dan prasarana di puskesmas, terdapat petugas khusus yang rutin melakukan kalibrasi sesuai jadwal.

"Kalo itu ada jadwalnya. Misalkan alatnya itu harus dikalibrasi setiap berapa bulan sekali gitu caranya. Kita juga ada CS yang rutin membersihkan kayak gitu." (drg_06)
Kemudian, jika terdapat kerusakan barang maka akan dilaporkan kepada tim asset dan tim asset akan mencoba melakukan perbaikan terlebih dahulu tetapi jika tidak bisa diperbaiki maka akan diajukan ke dinas kesehatan ataupun melakukan pemeliharaan sendiri dengan rekanan.

"Jadi kalo ada keluhan dari pelayanan nanti bisa melaporkan ke asset. Nanti dari asset itu biasanya merencakanan pemeliharaan dan melaporkan ke dinas kalo barangnya gak bisa diperbaiki. Nah kalo misal dari dinas tidak ada alokasi dana, kita biasanya melakukan pemeliharaan sendiri. Biasanya dari rekanan sih, rekanan atau PT yang punya MoU sama kita" (apt_08)

Ditinjau dari cara berpakaian petugas dalam memberikan pelayanan kesehatan di masa pandemi COVID-19 yaitu menggunakan APD level 2. Namun, untuk dokter gigi, perawat gigi, dan petugas yang bertugas dalam kegiatan swab menggunakan APD level 3 guna meminimalisir terjadinya penularan COVID-19 antara pasien dengan petugas. "Iya, kita disini menggunakan APD level 2 kecuali di poli gigi karna ada buka mulut nya jadi pakai APD level 3. Selain itu, yang biasa pakai APD level 3 itu petugas yang bertugas di swab karna disini ada pelayanan swab antigen dan PCR sama petugas yang jemput pasien yang positif covid." (TTK_09)

Berdasarkan hasil pengamatan peneliti, petugas kesehatan sudah menggunakan APD dengan baik. Dalam penyelenggaraan pelayanan kesehatan seluruh petugas di puskesmas menggunakan APD level 2 seperti menggunakan pakaian jaga, masker, gaun, haircap, dan faceshiled. Namun, di hari-hari 
tertentu untuk pelayanan di poli gigi dan pelayanan swab seluruh petugas yang bertugas menggunakan APD level 3 yang lebih lengkap seperti menggunakan jas hasmat, pengaman mata, pengaman wajah, penutup kepala, masker, sarung tangan bedah, serta sepatu boots.

Namun, beberapa informan menyatakan bahwa terdapat kendala dalam penggunaan APD saat pemberian pelayanan kesehatan seperti komunikasi menjadi agak sulit karena menggunakan masker serta merasa pengap dan tidak bisa bergerak dengan leluasa saat menggunakan jas hasmat.

"Kalo pakai jas hasmat susah, sesek dan pengap gitu trus gak bisa bergerak leluasa. Kemudian, untuk komunikasi dengan pasien juga susah karna masker kan double bahkan triple." (drg_07)

Untuk mengatasi kendala tersebut, petugas puskesmas berusaha untuk lebih mengeraskan volume suara saat berkomunikasi dengan pasien, serta membatasi jam tindakan pelayanan khususnya di poli gigi yaitu setiap senin dan kamis dari pukul 09.00 sampai 11.00. "Jadi harus dikerasin suaranya, nah di masa pandemi ini kita hanya melakukan tindakan di poli gigi itu setiap hari senin dan kamis saja dan kita batasi dari jam 9 sampai jam 11 biar kita tidak merasa terlalu pengap, sisanya hanya memberikan pelayanan konsultasi dan pemberian obat." (drg_07)

\section{b. Dimensi Kehandalan (reliability)}

Ditinjau dari dimensi kehandalan, di Puskesmas Kuta II tersedia SOP yang harus diikuti oleh seluruh petugas puskesmas. Dalam hal ini, SOP setiap poli tidak dipajang tetapi tersedia di dalam map dan diletakkan di masing - masing poli. SOP tersebut dipelajari, dimengerti, dan dikerjakan oleh setiap petugas guna dapat memberikan pelayanan yang baik dan tepat kepada pengunjung.

"Iya, masing - masing ruangan ada SOP. SOP itu tidak dipajang, SOP kita pelajari, kita mengerti dan kita kerjakan." (drg_07)

Pernyataan dari informan tersebut sesuai dengan hasil pengamatan peneliti yaitu untuk SOP masing - masing ruangan tidak dipanjang di dinding, hanya diletakkan didalam map dan SOP tersebut diletakan di meja yang berada di masing masing poli.

Agar pelayanan yang diberikan selalu sesuai dengan SOP yang berlaku maka pihak puskesmas selalu berusaha untuk mencukupi ketersediaan APD, BHP, dan sarana prasarana.

"Untuk itu kita usahakan untuk selalu mencukupi ketersediaan APD, bahan habis pakai, dan sarana prasarana." (KaPus_01)

Selain itu, pihak puskesmas juga melaksanakan audit internal dan audit klinis untuk melihat apakah pelayanan yang diberikan sudah sesuai dengan SOP yang ada. Audit ini dilaksanakan.

“..kita juga melakukan audit klinis dan audit internal dengan harapan pelayanan yang kita berikan selalu sesuai dengan SOP yang telah ditetapkan." (KaPus_01)

Kemudian dilihat dari kehadiran petugas, petugas selalu berusaha hadir tepat waktu dalam pemberian pelayanan kesehatan yakni pukul 07.30 sehingga petugas dapat mempersiapkan segala sesuatu yang diperlukan sebelum pelayanan kesehatan dimulai.

"Iya, karna kita semua dihimbau untuk datang itu jam 07.30 pagi dan mulai pelayanan jam 
08.00 pagi. Jadi 30 menit itu untuk prepare." (Lab_14)

Hal ini sesuai dengan hasil pengamatan peneliti dimana petugas kesehatan selalu datang tepat waktu sebelum pelayanan dimulai. Sehingga, pelayanan yang mulai dilaksanakan pada pukul 08.00 dapat berjalan dengan baik.

\section{c. Dimensi}

Daya

Tanggap

\section{(responsiveness)}

Berdasarkan daya tanggap dalam memberikan pelayanan kesehatan, saat berhadapan dengan pelanggan tindakan yang dilakukan petugas adalah menyambutnya dengan baik dengan menerapkan 3S (senyum, salam, sapa).

"Iya pastinya kita menerapkan 3S (senyum, salam, sapa) karena itu masuk ke visi misi dan bersikap baik kepada pasien biar pasien itu juga puas dengan pelayanan yang kita berikan. Ya walaupun senyum kita gak bisa diliat tapi ya kita usahakan itu tetep kita laksanakan" (Bidan_12)

Hal ini didukung berdasarkan hasil pengamatan peneliti dimana saat pelanggan datang ke puskesmas, pelanggan selalu sambut baik oleh petugas.

Kemudian, sebagian besar informan menyatakan bahwa waktu yang diperlukan dalam memberikan pelayanan yaitu rata - rata 5-15 menit. Namun, tidak menutup kemungkinan waktu yang diperlukan ini lebih dari 15 menit karena tergantung dari tindakan yang dilakukan.

"Kalo untuk non tindakan gak sampai lebih dari 15 menit. Kalo untuk tindakan, tergantung dari tindakannya seperti apa yang paling lama itu sampai 30 menit." (dr_05)
“Biasanya bisa 5-15 menit. Kalo dulu masih ada scalingnya bisa 40-60 menit. Kalo pencabutan yang lebih sulit ya bisa sampai 1 jam. Jadi tergantung tindakan di poli gigi." (drg_07)

Pernyataan informan tersebut sesuai dengan hasil pengamatan peneliti. Dimana peneliti mengamati bahwa dari pasien masuk ke poli untuk melakukan pemeriksaan sampai keluar poli tersebut rata - rata memerlukan waktu 5 sampai 15 menit. Begitu juga di loket pendaftaran saat pelanggan melakukan pendaftaran dan di pelayanan farmasi dari penyerahan resep sampai obat diberikan ke pelanggan.

Agar petugas dapat memberikan pelayanan yang tepat sesuai dengan kebutuhan pelanggan maka dilaksanakan briefing yang biasa dilakukan setiap hari saat apel pagi. Namun di masa pandemi COVID-19 seperti saat ini, briefing tersebut dilaksanakan dengan memberikan informasi melalui whatsapp grup.

"Iya, dulu sebelum pandemi kita rutin melakukan briefing kepada pegawai. Briefing ini kita lakukan setiap hari saat apel pagi. Tapi karena saat ini pandemi, jadi apel tidak dilakukan karena harus menjaga jarak. Nah briefingnya kita lakukan dengan memberikan informasi lewat WA grup." (KaPus_01)

Selain itu, petugas juga selalu mengikuti SOP yang berlaku agar dapat memberikan pelayanan yang tepat sesuai dengan kebutuhan pelanggan.

"Iya kita selalu sesuai SOP sih. Kalo diluar SOP kita nanti yang salah kalo ada sesuatu." (dr_04)

Kemudian, petugas juga melakukan anamnesis lebih lanjut untuk mengetahui tindakan yang seharusnya diberikan kepada pasien. Jika diperlukan pemeriksaan lab, maka akan dilakukan 
untuk dapat direncanakan suatu perawatan.

"Kita lakukan anamnesis kepada pasien, pemeriksaan kepada pasien. Setelah kita lakukan pemeriksaan, kita lakukan tes - tes yang mengarah pada diagnose suatu penyakit. Setelah kita melakukan diagnosa penyakit, kita lihat kondisinya dan kita rencanakan suatu perawatan." (drg_07)

Selanjutnya, jika di bagian farmasi petugas selalu melakukan pengecekan kembali terkait obat yang akan diberikan agar sesuai dengan kebutuhan pelanggan dan sesuai dengan yang telah diresepkan oleh dokter.

"Kalo di farmasi sih, kita sebelum menyerahkan ke pasien itu melakukan pengecekan obat apakah sudah sesuai dengan resep dokter atau belum" (apt_08)

\section{d. Dimensi Jaminan (assurance)}

Dalam menjaga keamanan puskesmas, puskesmas menggunakan CCTV untuk memantau segala kegiatan yang berlangsung. Rekaman CCTV ini berada di ruangan Kepala Puskesmas.

"Untuk keamanan puskesmas itu kita ada CCTV. Jadi untuk rekaman CCTV itu ada di ruangan kepala puskesmas. Kalo untuk satpam itu kita gak ada, sampai saat ini juga aman aman aja." (KaTU_02)

Kemudian, untuk menjaga keamanan dalam meminimalisir terjadinya penularan virus juga sudah dilakukan kegiatan mitigasi untuk memisahkan antara pasien infeksius dengan pasien non infeksius serta terdapat tim PPI dan tim keselamatan pasien.

"Kegiatan mitigasi juga sudah berjalan dengan baik untuk memisahkan antara pasien infeksius dan non infeksius untuk mencegah terjadinya penularan COVID - 19. Selain itu, kita juga ada tim pencegahan dan pengendalian infeksi dan tim keselamatan pasien." (KaPus_01)

Dalam pemberian pelayanan kesehatan, agar pasien selalu merasa aman dan tidak kecewa dengan tindakan yang diberikan maka petugas kesehatan selalu memberikan KIE dan memberikan informed consent terkait pelayanan yang akan diberikan.

"Sebelum melaksanakan tindakan, pasti kita berikan KIE dan melaksanakan informed consent. Jadi kita jelaskan tindakan apa yang kita lakukan kemudian efek samping nya apa. Kalo setuju ya kita lakukan tindakan tersebut." (dr_05)

Pernyataan petugas tersebut didukung dari hasil pengamatan peneliti yaitu petugas kesehatan selalu memberikan KIE agar pasien merasa aman dengan tindakan yang diberikan. Jika memang pasien menolak maka petugas tidak akan melakukan hal tersebut dan melakukan hal yang lain sesuai dengan yang telah disetujui oleh pasien.

Selain itu, petugas kesehatan juga berusaha meminimalisir terjadinya kesalahan dalam memberikan pelayanan salah satunya adalah dari pelayanan farmasi yakni obat yang memiliki kemasan yang mirip atau nama yang sama dengan dosis yang berbeda telah disiasati dengan menaruh obat tersebut ditempat yang berjauhan guna menghindari salah pengambilan obat yang akan diberikan kepada pasien.

"Kalo obat yang mirip itu sudah kita siasati dengan menaruh obatnya itu di tempat yang berjauhan gak nempel. Jadi supaya tidak ada kesalahan itu, kita cek kembali obat - obatnya 
sudah sesuai resep atau belum sebelum diserahkan ke pasien." (apt_08)

Namun, terkadang dalam suatu waktu tertentu tidak menutup kemungkinan terdapat kendala yang dapat menyebabkan pasien kecewa dengan pelayanan yang diberikan salah satu contohnya adalah di pelayanan laboratorium yang terdapat kendala dalam mengambil sampel darah karena pembuluh darah pasien kecil. Maka dari itu, petugas kesehatan selalu menjelaskan kembali terkait tindakan yang akan dilakukan.

"Nah, sebelum kita ambil darah itu kan kita cek lokasi pembuluh darahnya, selama kita gak yakin, kita jelaskan dulu ke pasiennya bahwa ini pembuluh darahnya kecil. Ada kemungkinan bakal sulit diambil. Kalo seandainya disini gak dapet, dijelaskan diawal kemungkinan akan diambil darah di tangan satunya. Jadi pasien sudah paham, baru kita ambil darahnya." (Lab_14)

Selain itu, pihak puskesmas juga menghimbau para petugas kesehatan untuk mengikuti pelatian seperti workshop, seminar, pelatihan PNS, ATLS/ACLS agar petugas selalu dapat memberikan pelayanan yang aman bagi pasien.

"Iya, dihimbau untuk ikut pelatihan seperti workshop, pelatihan - pelatihan PNS, seminar, dan juga ATLS atau ACLS." (KaPus_01)

\section{e. Dimensi Empati (emphaty)}

Ditinjau berdasarkan dimensi empati, jika terdapat pasien yang merasakan kesakitan maka petugas melakukan assessment kepada pasien untuk mengetahui skala nyeri yang dirasakan oleh pasien
"Kalo misalkan pasien kesakitan kita tanya dulu sampai sebatas mana sakitnya itu. Jadi kita assessment liat dulu skala nyerinya seberapa kemudian kita lakukan tindakan yang sesuai sama kebutuhan pasien." (Prwt_10)

Selain itu, petugas juga melakukan anamnesa singkat untuk mengetahui sakit yang dialami oleh pasien dan melakukan tindakan untuk mengatasi rasa sakit yang dialami oleh pasien.

"Jadi saat pasien datang dan dia kesakitan kita tanya dia sakitnya apanya, anamnesa singkat dulu untuk mengetahui sakitnya ya diagnosanya apa nih. Kemudian kita berikan obat anti nyeri terlebih dahulu, diberikan kompres kalo itu bisa membantu" (dr_05)

Kemudian, jika mendapatkan keluhan dari pasien petugas puskesmas selalu terbuka dalam menerima kritik dan saran sehingga nantinya puskesmas dapat melakukan perbaikan dan memberikan pelayanan yang lebih baik lagi.

"Kita terbuka menerima saran dan kritikan yang sifatnya membangun. Sehingga nantinya kita dapat memperbaiki yang kurang - kurang dan bisa memberikan pelayanan yang lebih baik kedepannya." (Bidan_12)

Petugas juga selalu menanggapi keluhan tersebut sesuai prosedur yang ada. Kemudian, keluhan tersebut nantinya akan dibahas dalam rapat tim keluhan pelanggan dan rapat tinjauan manajemen sehingga nantinya dapat memberikan umpan balik terkait dengan keluhan pelanggan tersebut.

"Kalo ada keluhan dari pelanggan itu kita tanggapi sesuai prosedur yang ada dan kita bahas dalam rapat tim keluhan pelanggan, rapat tinjauan manajemen (RTM) kemudian memberikan umpan balik keluhan pelanggan." (KaPus_01) 


\section{DISKUSI}

\section{Strategi Berdasarkan 4 Prinsip Penjaminan Mutu}

\section{a. Fokus Terhadap Pelanggan}

Pelanggan merupakan fokus utama dalam suatu pelayanan kesehatan sehingga seluruh pelayanan yang diberikan harus berdasarkan pada kebutuhan dan harapan pelanggan. Untuk dapat memenuhi kebutuhan/harapan pelanggan tersebut diperlukan adanya suatu eksplorasi dan pemahaman dari pemberi pelayanan kesehatan (ReyesAlczar et al., 2012). Ditinjau dari fokus terhadap pelanggan, Puskesmas Kuta II berusaha untuk selalu memenuhi kebutuhan/harapan pelanggan dengan mengumpulkan informasi melalui kotak saran, sosial media, kuesioner kepuasan pelanggan, rapat lintas sektor, musrenbang, serta rapat dengan kader posyandu. Sebagai upaya tindaklanjut, informasi mengenai kebutuhan/harapan pelanggan tersebut akan dikoordinasikan oleh tim keluhan pelanggan dan pihak pimpinan sehingga dapat memberikan umpan balik kepada pelanggan. Selain itu, kegiatan yang telah disetujui juga akan dituangkan dalam RUK puskesmas. Dalam hal ini dapat dilihat bahwa penanganan terkait kebutuhan/harapan pelanggan yang dilakukan oleh Puskesmas Kuta II berjalan baik dengan melakukan koordinasi yang baik antar petugas. Hal ini sesuai dengan penelitian Putri and Riswandha (2019) yang menyatakan bahwa dengan tersedianya sistem pengaduan maka dapat mempermudah masyarakat untuk menyampaikan kebutuhan atau harapannya. Jika kebutuhan/harapan pelanggan tersebut ditangani dengan baik serta dapat memberikan umpan balik kepada pelanggan maka pelanggan akan merasa sangat dihargai.

\section{b. Fokus pada Sistem dan Proses}

Berfokus pada sistem dan proses, berdasarkan hasil wawancara dengan informan jika dilihat dari sumber daya manusia di Puskesmas Kuta II masih belum memadai, khususnya saat ini di masa pandemi COVID-19 yang sedang digencarkan kegiatan vaksinasi sehingga terdapat petugas yang harus bertugas keluar dan menyebabkan tenaga di puskesmas berkurang. Selain karena tugas keluar, puskesmas juga kekurangan tenaga sopir, admin, ahli gizi, dan rekam medis. Untuk mengatasi hal tersebut, puskesmas berusaha memaksimalkan SDM yang ada dalam bekerja. Namun jika setiap petugas memiliki banyak tugas dan tanggungjawab, hal ini akan berpengaruh terhadap tingginya beban kerja yang dialami oleh setiap petugas. Menurut Sarda, Ilyas and Kadir (2018) beban kerja yang tinggi akan berpengaruh terhadap stress kerja. Selain itu, puskesmas juga telah mengajukan permohonan penambahan pegawai ke dinas kesehatan.

Dalam suatu organisasi, ketersediaan dana merupakan suatu hal yang sangat penting karena dana tersebut digunakan untuk menyelenggarakan upaya kesehatan yang lebih merujuk kepada seluruh biaya investasi dan biaya operasional (Setyawan, 2018). Pandemi COVID-19 menyebabkan terjadinya penurunan pendapatan di Puskesmas Kuta II. Maka dari itu, puskesmas berusaha untuk mengelola 
dana tersebut dengan mengatur RKA dengan menggunakan skala prioritas sehingga dana yang tersedia cukup untuk kegiatan dan kebutuhan yang menjadi prioritas di Puskesmas Kuta II. Dana yang digunakan Puskesmas Kuta II untuk menunjang segala kebutuhan dan kegiatan di puskesmas berasal dari pendapatan BLUD yang terdiri dari JKN dan retribusi, DAK non fisik, serta dana yang bersumber dari APBD. Adapun dana yang dikelola oleh puskesmas adalah pendapatan BLUD yang bersumber dari JKN dengan proporsi alokasi dana sebesar $60 \%$ untuk jasa pelayanan serta $40 \%$ untuk operasional di puskesmas. Begitu juga dengan dana yang bersumber dari retribusi dengan proporsi $60 \%$ untuk jasa pelayanan serta $40 \%$ untuk operasional sesuai dengan tarif yang tercantum dalam peraturan daerah mengenai retribusi.

Kemudian, untuk DAK non fisik terdapat perubahan dalam penggunaannya yaitu yang dulunya hanya untuk kegiatan UKM tetapi saat ini karena terjadi pandemi COVID-19 dan terdapat beberapa UKM yang belum dapat dilaksanakan maka dana tersebut dibagi yaitu sebesar $60 \%$ untuk kegiatan UKM dan $40 \%$ dari dana tersebut digunakan untuk penanganan COVID-19. Hal ini sesuai dengan arahan dari Peraturan Menteri Kesehatan RI Nomor 12 Tahun 2021 yakni pengalokasian dana BOK (DAK non fisik) sebagai upaya pencegahan dan pengendalian COVID-19 sebesar 35\% sampai maksimal 40\%. Pengalokasian dana ini diarahkan untuk kegiatan prioritas seperti penguatan kegiatan tracing dan testing serta pengadaan Alat Pelindung Diri (Menteri Kesehatan RI, 2021). Selain menggunakan DAK non fisik, penanganan COVID-19 juga menggunakan dana yang berasal dari APBD yang dikelola oleh dinas kesehatan.

Selain itu, jika dilihat dari sarana dan prasarana yang ada saat ini dapat dikatakan cukup. Di masa pandemi COVID-19 terdapat penambahan sarana dan prasarana guna dapat memberikan pelayanan yang optimal kepada pelanggan dengan tetap menerapkan protokol kesehatan. Adapun sarana dan prasarana tersebut adalah tempat cuci tangan yang diletakkan di depan gedung, terdapatnya poli infeksius bagi pasien yang memiliki gejala yang merujuk pada COVID-19, terdapatnya pelayanan swab antigen dan swab PCR, serta penambahan sekat pembatas transparan di bagian loket pendaftaran guna meminimalisir terjadinya penularan COVID-19 antara pasien dengan petugas. Hal ini sesuai dengan arahan yang diberikan oleh kementerian kesehatan yaitu puskesmas harus menyediakan ruangan pemeriksaan khusus bagi pasien yang memiliki gejala yang merujuk pada COVID-19, menyediakan tempat cuci tangan, serta memberikan sekat transparan antara pasien dan petugas (Kemenkes RI, 2020b). Kemudian, puskesmas juga memiliki rencana untuk sarana dan prasarana seperti melakukan perbaikan gedung, menambah incenerator, pinter, komputer, dan mobil puskesmas agar dapat meningkatkan mutu pelayanan kesehatan.

Dalam penyelenggaraan pelayanan kesehatan, seluruh petugas puskesmas selalu mengikuti SOP yang ada. Namun, dalam memberikan pelayanan di masa pandemi COVID-19 terdapat beberapa 
kendala yang dirasakan oleh petugas seperti harus menjaga jarak, pelayanan di poli gigi yang memiliki risiko tinggi terhadap penularan COVID-19 karena melakukan tindakan yang mengharuskan membuka mulut, terbatasnya kegiatan on call pasien, serta kegiatan posyandu yang belum dapat dilaksanakan. Meskipun begitu, puskesmas berusaha untuk mengatasi kendala tersebut dengan kegiatan mitigasi untuk memisahkan pasien infeksius yang memiliki gejala panas batuk, dan pilek yang merujuk pada COVID-19 dengan pasien yang tidak memiliki gejala tersebut, terdapatnya identifikasi risiko, adanya pembatasan pemberian pelayanan tindakan di poli gigi yaitu hanya setiap hari senin dan kamis, menggunakan APD saat kegiatan on call pasien yakni APD level 2 jika pasien tidak terkonfirmasi positif COVID-19 dan APD level 3 jika pasien terkonfirmasi COVID-19, serta lebih memanfaatkan teknologi informasi untuk kegiatan posyandu dengan memberikan informasi atau edukasi kepada masyarakat dan dibantu oleh kader posyandu.

\section{c. Fokus Terhadap Data untuk Mengambil Keputusan}

Menurut Kamus Besar Bahasa Indonesia, data merupakan suatu bahan nyata yang dapat dijadikan sebagai dasar kajian untuk melakukan analisis, menarik kesimpulan, maupun pengambilan keputusan. Ditinjau dari fokus terhadap data untuk mengambil keputusan, data yang digunakan puskesmas untuk mengidentifikasi masalah, merencanakan atau menguji suatu solusi, serta mengukur kinerja di puskesmas yaitu menggunakan capaian program, capaian kinerja, IKM, melihat dari ketersediaan sarana dan prasarana melihat dari hasil audit internal dan audit klinis, serta melihat dari hasil SMD/MMD.

\section{d. Fokus pada Kerja Tim}

Dalam suatu instansi atau organisasi, kerjasama tim merupakan hal yang sangat penting karena kerjasama tim yang baik dapat menghasilkan suatu sinergi yang positif dalam tercapainya suatu tujuan organisasi (Judge, 2008). Ditinjau berdasarkan kerja tim, puskesmas rutin melaksanakan rapat UKM, UKP, admen seriap minggu, RTM setiap 3 bulan, dan rapat rutin setiap bulan untuk melaporkan dan memantau hasil capaian puskesmas dengan membandingkan antara rencana kerja yang telah ditetapkan sebelumnya dengan hasil yang tercapai saat ini. Selain itu, dalam membangun kerja tim yang baik Puskesmas Kuta II juga rutin melaksanakan apel setiap hari di pagi hari yang di pimpin oleh kepala puskesmas guna dapat menjalin komunikasi yang baik antar petugas, membangun semangat kerja, serta membina kekompakan atau kerjasama antar petugas. Namun, apel ini tidak dilaksanakan lagi karena pandemi COVID-19 sehingga kepala puskesmas hanya rutin memberikan informasi melalui whatsapp grup dan diharapkan antar petugas tetap bekerjasama dengan baik di masa pandemi COVID-19. Hal ini sejalan dengan penelitian Prodea et al. (2019) yang menyatakan bahwa briefing pagi memiliki pengaruh terhadap motivasi kerja pegawai dan menciptakan kerja tim yang baik 
sehingga tujuan dari suatu organisasi dapat tercapai.

\section{Strategi Berdasarkan 5 Dimensi Mutu}

\section{a. Dimensi Bukti Fisik (tangibles)}

Ditinjau dari bukti fisik, saat ini peralatan kesehatan dan persediaan obat di puskesmas sudah memadai, puskesmas juga rutin melakukan sterilisasi terhadap sarana dan prasarana, rutin melaksanakan pemeliharaan sarana dan prasarana dengan kalibrasi dan melakukan pelaporan kepada tim asset jika terdapat kerusakan barang. Kemudian, cara berpakaian petugas dalam memberikan pelayanan kesehatan di masa pandemi COVID-19 yaitu menggunakan APD level 2. Namun, pada hari - hari tertentu untuk dokter gigi, perawat gigi dan petugas yang bertugas dalam pelayanan swab menggunakan APD level 3. Pemakaian APD dalam pemberian pelayanan kesehatan ini sesuai dengan arahan kementerian kesehatan guna mencegah terjadinya penularan yang kemungkinan terjadi antara pasien dengan petugas puskesmas (Kemenkes RI, 2020b). Dalam hal ini, Puskesmas Kuta II berusaha semaksimal mungkin untuk memberikan fasilitas yang baik guna dapat meningkatkan kenyamanan dan kepuasan pelanggan yang kemudian akan berpengaruh terhadap mutu pelayanan kesehatan. Penelitian Taekab (2019) menyatakan bahwa bukti fisik yang meliputi sarana dan prasarana seperti kebersihan dan kenyamanan fasilitas, peralatan kesehatan yang baik dan memadai serta penampilan dari petugas kesehatan yang rapi berhubungan dengan kepuasan pasien yang mampu berpengaruh terhadap mutu pelayanan kesehatan di puskesmas.

\section{b. Dimensi Kehandalan (reliability)}

Ditinjau dari dimensi kehandalan, seluruh petugas Puskesmas Kuta II selalu mengikuti SOP yang ada dalam memberikan pelayanan kesehatan guna meminimalisir terjadinya kesalahan. Penelitian Kenedi, Lanin dan Agus (2018) menyatakan bahwa dengan tersedianya SOP dan jika petugas selalu patuh dalam mengikuti SOP maka dapat mengurangi tingkat kesalahan atau kelalaian serta dapat meningkatkan efisiensi dan efektivitas dalam pemberian pelayanan kesehatan. Agar seluruh petugas mengikuti SOP tersebut, pihak puskesmas selalu berusaha untuk mencukupi ketersediaan APD, bahan habis pakai, serta sarana dan prasarana di puskesmas. Selain itu, pihak puskesmas juga melaksanakan audit internal dan audit klinis. Audit merupakan suatu kegiatan yang bertujuan untuk mengumpulkan informasi dengan pemeriksaan atau penilaian dengan cara membandingkan antara standar yang telah ditetapkan dengan apa yang dilaksanakan di lapangan (Kemenkes RI, 2018). Kemudian, petugas kesehatan juga selalu hadir tepat waktu dalam pemberian pelayanan kesehatan. Seluruh petugas kesehatan dihimbau untuk datang 30 menit sebelum pelayanan dimulai yaitu pada pukul 07.30. Sehingga, saat pelayanan kesehatan mulai pukul 08.00 seluruh petugas sudah siap memberikan pelayanan.

\section{c. Dimensi Daya}

Tanggap (responsiveness) 
Dimensi daya tanggap berkaitan dengan kecepatan dan ketepatan petugas kesehatan dalam memberikan pelayanan kepada pasien. Berdasarkan hasil wawancara dan observasi peneliti didapatkan bahwa dalam memberikan pelayanan kesehatan petugas selalu bersikap dengan baik dan waktu yang diperlukan dalam memberikan pelayanan tidak lama yaitu berkisar 5 - 15 menit. Menurut Kemenkes RI (2008) standar waktu pelayanan dalam pemeriksaan pasien di ruang pemeriksaan yaitu minimal 15 menit. Kemudian, agar petugas dapat memberikan pelayanan yang tepat sesuai dengan kebutuhan pelanggan petugas selalu mengikuti SOP, melakukan anamnesis dan pemeriksaan lebih lanjut, dan melakukan pengecekan kembali terkait obat yang akan diberikan kepada pasien.

\section{d. Dimensi Jaminan (assurance)}

Ditinjau dari dimensi jaminan, sistem keamanan di Puskesmas Kuta II saat ini sudah baik. Puskesmas menggunakan CCTV untuk memantau seluruh kegiatan yang dilaksanakan. Kemudian, di masa pandemi COVID-19 puskesmas juga mengoptimalkan kegiatan mitigasi untuk meminimalisir penularan COVID-19 dengan memisahkan pasien infeksius dengan pasien non infeksius. Selain itu, di puskesmas juga terdapat tim PPI yang bertugas untuk mencegah terjadinya infeksi pada pengunjung dan petugas puskesmas serta tim keselamatan pasien yang bertanggungjawab atas keselamatan pasien dalam mendapatkan pelayanan kesehatan di puskesmas. Pihak puskesmas juga menghimbau petugas untuk mengikuti beberapa pelatihan agar petugas dapat memberikan pelayanan yang aman bagi pelanggan. Petugas kesehatan juga selalu memberikan KIE, informed consent terkait pelayanan yang akan diberikan, serta berusaha meminimalisir terjadinya kesalahan agar pasien merasa aman dan tidak kecewa dengan pelayanan yang diberikan. Menurut (Zainafree et al, 2016) pelayanan yang bermutu harus dapat memberikan informasi yang jelas kepada pasien terkait pelayanan kesehatan yang dilakukan. Jika jaminan pelayanan kesehatan baik maka akan berpengaruh terhadap kepuasan pasien.

\section{e. Dimensi Empati (emphaty)}

Dimensi empati dalam hal ini terkait respon petugas dalam memahami masalah yang dirasakan oleh pelanggan. Dalam menangani kesakitan yang dialami oleh pasien, petugas akan melakukan assessment dan anamnesa singkat yang dilanjutkan dengan melakukan tindakan sesuai kebutuhan pasien. Selain itu, petugas juga sangat terbuka dalam menerima kritik dan saran jika terdapat pelanggan yang mengutarakan keluhan terkait pelayanan kesehatan yang diperoleh. Nantinya, keluhan tersebut akan ditanggapi sesuai prosedur yang ada dan akan dibahas dalam rapat tim keluhan pelanggan dan rapat tinjauan manajemen sehingga kedepannya dapat memberikan umpan balik terkait keluhan pelanggan tersebut. Menurut A.Parasuraman, Zeithaml and Berry (1988) bentuk perhatian (emphaty) adalah salah satu karakteristik yang dapat digunakan pelanggan untuk menilai suatu mutu pelayanan kesehatan. Semakin baik empati pelayanan kesehatan yang dilihat dan dirasakan oleh pelanggan maka semakin baik juga kepuasan yang 
dirasakan oleh pelanggan yang kemudian dapat berpengaruh terhadap mutu pelayanan kesehatan (Zainafree et al, 2016)

\section{KESIMPULAN}

Strategi puskesmas berdasarkan 4 prinsip penjaminan diantaranya: (1) fokus terhadap pelanggan dengan memberikan umpan balik kepada pelanggan; (2) fokus pada sistem dan proses, meliputi: memaksimalkan SDM yang ada dalam bekerja, menambah beberapa sarana dan prasarana di masa pandemi, serta menyusun RKA dengan skala priotitas; (3) fokus terhadap data untuk mengambil keputusan dengan menggunakan capaian program puskesmas, capaian kinerja puskesmas, hasil SMD/MMD, serta hasil audit internal dan klinis; dan (4) fokus pada kerja tim dengan melaksanakan rapat serta melaksanakan briefing.

Strategi puskesmas berdasarkan 5 dimensi mutu diantaranya: (1) dimensi bukti fisik: berusaha menata segala sesuatunya dengan baik, rutin melakukan sterilisasi dan pemeliharaan sarana, serta menggunakan APD; (2) dimensi kehandalan: mencukupi ketersediaan APD, BHP, sarana dan prasarana, melaksanakan audit internal dan klinis, serta ketepatan waktu petugas dalam memberikan pelayanan; (3) dimensi daya tanggap: memberikan pelayanan yang cepat dan tepat; (4) dimensi jaminan: menjaga keamanan pasien dengan terdapatnya kegiatan mitigasi dan meminimalisir terjadinya kesalahan kepada pasien; (5) dimensi empati dengan selalu bersikap baik dengan menangani pasien sesuai kebutuhan dan terbuka dalam menerima kritik dan saran.

\section{SARAN}

Puskesmas sebaiknya meningkatkan manajemen SDM dengan mengatur SDM dengan baik menggunakan WISN untuk mengitung kembali terkait kebutuhan tenaga kerja berdasarkan beban kerja yang ada agar dapat meminimalisir terjadinya overlapping ataupun beban kerja yang tinggi dalam bekerja serta meningkatkan kembali terkait penataan ruangan di puskesmas agar pelayanan yang diberikan dapat berjalan lebih baik dan pasien merasa puas dan nyaman dengan fasilitas yang disediakan. Bagi peneliti selanjutnya diharapkan dapat memperluas ruang lingkup penelitian dengan menambah informan/melihat berdasarkarkan sudut pandang masyarakat sebagai penerima pelayanan kesehatan.

\section{UCAPAN TERIMAKASIH}

Peneliti mengucapkan terimakasih kepada dosen pembimbing, dosen penguji, keluarga, sahabat, Kepala Puskesmas Kuta II, seluruh pegawai di Puskesmas Kuta II, serta seluruh pihak yang telah membantu dan mendukung dalam penelitian ini.

\section{DAFTAR PUSTAKA}

A.Parasuraman, Zeithaml, V. A. and Berry, L. L. (1988) 'SERVQUAL: A Multiple-Item Scale for Measuring Consumer Perception of Service Quality - A.Parasuraman - 1988', Journal of Retailing.

Aminingrum, T. E. R. .; and Niswah, F. (2013) 'Strategy for Improving the Quality of Health Service in the Community Health', Jurnal Ilmu Administrasi Negara, 1(3), pp. 1-9. 
Azrul, azwar (2010) Pengantar administrasi kesehatan, edisi ke enam., Bina rupa aksara; Jakarta.

Azwar, A. (1994) Program Menjaga Mutu Pelayanan Kesehatan. Yayasan Penerbitan IDI.

Dinas Kesehatan Kabupaten Badung (2020) Profil Kesehatan Dinas Kesehatan Kabupaten Badung 2019.

Judge, S. R. (2008) Perilaku Organisasi. 12 th edn. Jakarta: Salemba Empat.

Kamus Besar Bahasa Indonesia.. Available at: $\quad$ https://jagokata.com/artikata/data.html (Accessed: 5 June 2021).

Kemenkes RI (2008) 'Permenkes : 129/Menkes/SK/II/2008 TENTANG STANDAR PELAYANAN MINIMAL RUMAH SAKIT'

Kemenkes RI (2018) 'Pedoman Audit Internal dan Pertemuan Tinjauan Manajemen Fasilitas Kesehatan Tingkat Pertama'.

Kemenkes RI (2020a) Kesiapsiagaan Menghadapi COVID-19, Kemenkes RI. Available at: https://www.kemkes.go.id/folder/vi ew/full-content/structure-faq.html (Accessed: 9 January 2021).

Kemenkes RI (2020b) Petunjuk Teknis Pelayanan Puskesmas Pada Masa Pandemi Covid-19, kemenkes RI.

Kenedi, J., Lanin, D. and Agus, Z. (2018) 'Analisis Pengadaan Alat Kesehatan Di Rumah Sakit Umum Daerah Padang Pariaman Tahun 2017', Jurnal Kesehatan Andalas, 7(Supplement 2), p. 9. doi: 10.25077/jka.v7i0.818.

Menteri Kesehatan RI (2021) Peraturan Menteri Kesehatan RI Nomor 12 Tahun
2021 Tentang Petunjuk Teknis Penggunaan Dana Alokasi Khusus Non Fisik Bidang Kesehatan Tahun Anggaran 2021.

'Peraturan Menteri Kesehatan Republik Indonesia Nomor 75 Tahun 2014 Tentang Pusat Kesehatan Masyarakat'

Prodea, R. et al. (2019) 'Pengaruh Briefing Pagi Terhadap Motivasi Kerja Pegawai pada Departemen Housekeeping pada Industri Resort di Indonesia', pp. 50-55.

Putri, D. M. and Riswandha, M. N. (2019) 'Sistem Informasi Pengaduan ( Komplain ) Pelayanan Kesehatan Pada Puskesmas Bangil Menggunakan Metode Kuantitatif dan Kualitatif', jurnal insand comtech. Reyes-Alczar, V. et al. (2012) 'Critical Success Factors for Quality Assurance in Healthcare Organizations', Quality Assurance and Management. doi: 10.5772/33081.

Sarda, A., Ilyas, G. B. and Kadir, I. (2018) 'Pengaruh kepemimpinan, beban kerja dan kondisi kerja terhadap stres perawat di uptd kesehatan puskesmas Palanro Kecamatan Mallusetasi Kabupaten Barru', YUME: Journal of Management.

Setyawan, F. E. B. (2018) 'Sistem Pembiayaan Kesehatan', MAGNA MEDICA: Berkala Ilmiah Kedokteran dan Kesehatan. doi: 10.26714/magnamed.2.4.2018.57-70. Taekab, D. (2019) 'Analisis Persepsi Pasien Terhadap Mutu Pelayanan Puskesmas Dan Hubungannya Dengan Kepuasan Pasien Rawat Jalan Di Puskesmas Leyangan 
Arc. Com. Health • Desember 2021

p-ISSN 2302-139X e-ISSN 2527-3620

Kabupaten Semarang Tahun 2018',

Jurnal Kesehatan Masyarakat (eJournal), 7(1), pp. 31-40.

Zainafree et al (2016) 'Hubungan Mutu

Pelayanan Kesehatan Dengan

Tingkat Kepuasan Pasien Rawat

Inap di Puskesmas Halmahera Kota

Semarang', 4(1), pp. 44-47. 